\title{
ACTIVITY OF NATURAL KILLER CELLS DURING HIV-1 INFECTION IN BRAZILIAN PATIENTS
}

\author{
Danilo Ferreira Nunes, Anderson Carvalho and Alberto José da Silva Duarte
}

RHCFAP/3040

NUNES DF et al. - Activity of natural killer cells during HIV-1 infection in Brazilian patients. Rev. Hosp. Clín. Fac. Med. S. Paulo 56(3):75-78, 2001.

Natural killer cells are increasingly being considered an important component of innate resistance to viruses, but their role in HIV infection is controversial. Some investigators have found that natural killer cells do not confer a protective effect during the progression of HIV disease, whereas others have shown that natural killer cells may be protective and retard the progression of the disease, either through their lytic activity or by a chemokine-related suppression of HIV replication. In this study, we analyzed functional alterations in the activity of natural killer cells during HIV-1 infection using a natural killer cells activity assay with K562 cells as targets.

Results: Our results show that the activity of natural killer cells decreases only in the advanced phase of HIV infection and when high (40:1) effector cell-target cell ratios were used. The depression at this stage of the disease may be related to increased levels of some viral factors, such as gp120 or gag, that interfere with the binding capacity of natural killer cells, or to the decreased production of natural killer cells -activity-stimulating cytokines, such as IFN-a and IL-12, by monocytes, a subset of cells that are also affected in the late stage of HIV infection. The data suggest that decreased natural killer cells cell activity may contribute to the severe impairment of the immune system of patients in the late stages of HIV infection.

\section{DESCRIPTORS: HIV infection. Natural killer cells.}

Natural killer cells (NK) are active in the earliest stages of the host defense and have been increasingly recognized as an important component of innate resistance. In fact, NK cells display broad specificity, rapid activation, and play a role in cell-mediated cytotoxicity and lymphokine production. In contrast to B and T lymphocytes, which are involved in specific (acquired) immunity, NK cells possess an apparently innate ability to respond to tumor cells and cells infected by intracellular pathogens, such as viruses ${ }^{1}$.

There have been controversial reports on the role of the NK cells in the pathogenesis of HIV infection. While some investigators have found that NK cells do not confer a protective effect against the progression of HIV disease $^{2,3}$, others have shown that NK cells may play a protective role in HIV infection $^{4,5}$.

HIV infection is a public health concern in Brazil and occurs mainly in highly populated areas, such as the State of São Paulo, which has been responsible for half of the cases reported in the last 20 years $^{6}$. A cohort has been followed since 1985 to study HIV disease progression in São Paulo ${ }^{7}$. In the

From the Department of Dermatology, Laboratory of Allergy and Clinical Immunology (LIM 56), Hospital das Clínicas, Faculty of Medicine, University of São Paulo and the Emílio Ribas Infectology Institute, São Paulo. present study, we report preliminary results on the functional analyses of NK cells activity during HIV-1 infection in this cohort.

\section{PATIENTS AND METHODS}

Forty-one HIV-1-infected patients (30 males and 11 females) were evaluated. The mean $( \pm \mathrm{SD})$ age of patients was $33 \pm 7$ years old. Twenty-two were homosexual or bisexual men, 14 individuals were heterosexuals, 4 were intravenous drug users, and for one case the infection route was unknown. All participants gave written informed consent for the present study. The subjects were classified according to the $\mathrm{T}$ 
CD4+ cell count criteria ${ }^{8}$ : Group I, > 500 cell $/ \mathrm{mm}^{3}$; Group II, 200-500 cells/ $\mathrm{mm}^{3}$; and Group III, $<200$ cells $/ \mathrm{mm}^{3}$.

The patients were arranged in groups according to their T CD4+ cell counts. The mean $( \pm \mathrm{SE}) \mathrm{CD} 4+\mathrm{T}$ cell counts for the three groups were as follows: for Group I $(n=11), 724 \pm 156$; for Group II $(\mathrm{n}=14), 373 \pm 87$; and for Group III $(\mathrm{n}=16), 80 \pm 55$ cells $/ \mathrm{mm}^{3}$. Fifteen healthy volunteers from the laboratory staff were evaluated as the control group (T CD4+ count: $829 \pm$ 346 cells $/ \mathrm{mm}^{3}$ ).

NK cell activity was determined as previously described ${ }^{2}$. Briefly, mononuclear cells (PBMC) were separated from heparinized peripheral blood and resuspended to $2-4 \times 10^{6}$ cells $/ \mathrm{mL}$ supplemented with $20 \%$ fetal calf serum (FCS) (Laborclin, Campinas, Brazil). K562 cells were labeled with ${ }^{51} \mathrm{Cr}$ (sodium chromate, CNEN, SP, Brazil) and used as targets. The patients' mononuclear cells and ${ }^{51} \mathrm{Cr}$ labeled K562 cells ( 1 x $10^{5}$ cells/well) were added in triplicate to microplates with U-bottom wells (Corning Plastics, NY, USA) at the ratios of 40:1, 20:1, 10:1, and 5:1 effector cells to target cells ${ }^{5}$. The plates were centrifuged at $800 \mathrm{rpm}$ and incubated for $4 \mathrm{~h}$ at $37^{\circ} \mathrm{C}$ in $5 \% \mathrm{CO}_{2}$. The radioactivity released to the supernatants in each well was counted with a gamma counter (Packard Instrument CO., Downers Grove, IL, USA). The spontaneous release was determined from target cells incubated with medium only, and the total release was measured by incubation of the cells in $1 \%$ Triton X100 in PBS. The percentage of specific lysis by the patient specimen was calculated as an arithmetic mean as follows: (mean cpm experimental mean cpm spontaneous release) / ( mean cpm total release - mean cpm spontaneous release) $\mathrm{x} 100$. The statistical analysis was performed by using paired $t$-tests to compare the NK activity in the groups.

\section{RESULTS}

The results from these experiments show that only patients with advanced HIV disease (Group III), where T CD4+ counts were below 200 cells/ $\mathrm{mm}^{3}$, showed decreased NK cell activity $(45 \pm 22)$ compared to healthy control individuals $(66 \pm 18)$ in the $40: 1$ effector cells/target cells ratio group $(p<0.05)$. We did not observe statistical differences between the other groups using paired $t$-tests to compare the groups. The results are summarized in figure 1.

For lymphocyte proliferation assays, PBMCs $\left(2 \times 10^{5}\right.$ cell/well) were cultivated in triplicate in microplates (Costar, Cambridge, MA, USA) at $37^{\circ} \mathrm{C}$ with $5 \% \mathrm{CO}_{2}$ in the presence of medium only or with $5 \mathrm{mg} / \mathrm{mL}$ of phytohemagglutinin (PHA). The cells were incubated for 3 days and pulsed for an additional $18 \mathrm{~h}$ with $0.5 \mathrm{mCi} /$ well $\left[{ }^{3} \mathrm{H}\right]$ thymidine $(2 \mathrm{mCi} / \mathrm{mM}$, Radiochemical Center, Amersham, UK) before being harvested. The cell-bound radioactivity was measured in a beta scintillation counter (Beckman, Palo Alto, CA, USA). The mean counts per minute of triplicate wells were calculated and the results were expressed as the difference between the counts per minute of stimulated and non-stimulated cultures. A decreasing lymphocyte proliferation response was observed with the progression of the disease, as has been previously reported ${ }^{7}$. Patients in Group I showed a mean \pm SD of $20,259 \pm$ 3,028 DCPM; patients in Group II, $13,615 \pm 2,739$; and patients in Group III, 7,649 $\pm 1,813$. Lymphocytes from the control group proliferated significantly more than in groups with the HIV patients $(\mathrm{CPM}=34,067 \pm 4,420$, $\mathrm{p}<0.05)$.

\section{DISCUSSION}

Our results show that NK cell activity decreased only in the advanced phases of HIV infection and when a high effector cell to target cell ratio

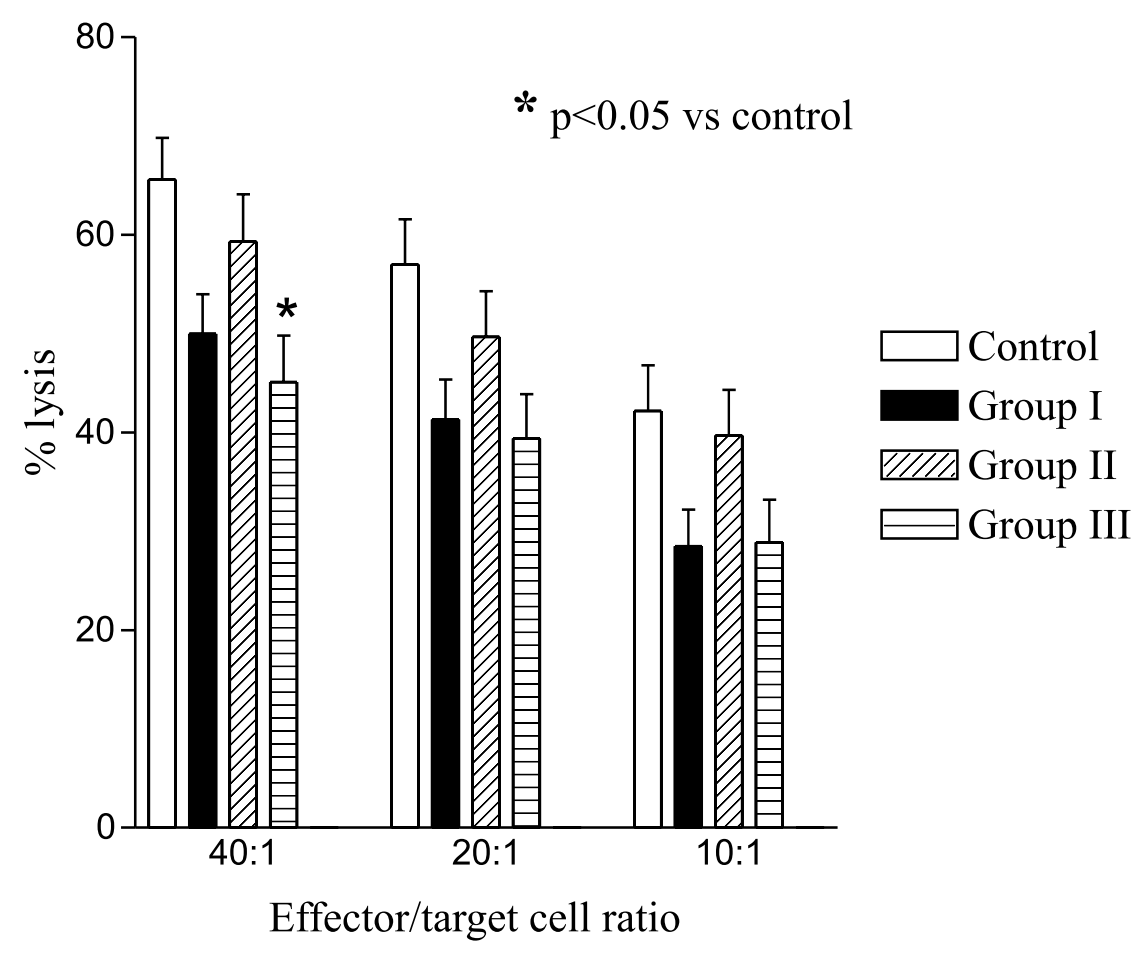

Figure 1 - Natural killer activity in HIV-1-infected patients. 
(40:1) was used. A decrease has been reported in NK activity by nearly $75 \%$ in HIV-1-infected patients with less than 400 cells $/ \mathrm{mm}^{3}$ compared to uninfected individuals ${ }^{3}$. Accordingly, we observed a marked depressed cellular immunity, as assessed by decreased T-cell lymphocyte proliferation, in HIV-1 infected patients with $\mathrm{T}$ CD4+ counts below 500 cells/ $/ \mathrm{mm}^{3,7,10}$. Other investigators have observed depression in NK cells from the beginning of the HIV infection, when cellular immunity depression was less evident $^{5}$. In contrast, Ullum et al. did not observe any difference in NK cells activity throughout HIV-1 infection, although the interferon-g induced NK activity was depressed in GIV patients compared to GII and GIII patients ${ }^{4}$.

The mechanism of reduced NK cell activity in HIV-1-infected patients is still unknown. One possibility is that it may result from low levels of some cytokines, such as IFN-g, which is an important activator of NK cells and the production of which is only affected in the late phases of HIV disease ${ }^{4}$. The progressive decrease in the levels of other cytokines that are also important regulators of NK cell activity (such as IL-2, IL-12, and IL-15) during HIV infection may also contribute to the loss of NK cell activity. In fact, several studies have documented at least partial recovery of this in vitro activity through the addition of these cytokines ${ }^{9,10,11}$. Moreover, monocytes are only significantly affected in late phases of HIV infection, and they may be a consistent source of IL-12 and IL-15 ${ }^{11}$.

Alternatively, it has been shown that serum from AIDS patients has a dose-dependent inhibitory effect on normal NK cells. Most of this inhibition is caused by immunoglobulin G, but other factors, such as gp120, may also contribute to this effect ${ }^{12}$. More recently, it has been shown that $\mathrm{NK}$ cells have the capacity to secrete $\mathrm{CC}$ chemokines in vivo, and therefore, suppress HIV replication by CCchemokine-mediated mechanisms in addition to the classic NK-mediated lytic mechanisms ${ }^{13}$. Viral products, such as gp120 and gag, whose levels are usually increased in the late phases of the infection, may interfere with NK activity, probably through the inhibition of the target binding capacity of the effector cells ${ }^{14}$.

In the light of the increasing evidence of an important role for NK cells during HIV infection, we suggest that decreased NK cell activity may be part of the severe impairment of the immune system observed in the advanced phase of the disease; however, further longitudinal studies will be necessary to investigate whether combined antiretroviral therapy could change NK activity.

\section{ACKNOWLEDGMENTS}

We thank Gil Benard and Jorge Casseb for their critical reviews of this manuscript and Noemia Orii for technical assistance.

Support: Partially supported by the "Fundação de Amparo à Pesquisa do Estado de São Paulo (FAPESP)" 90/ 4798-3, Brazilian Ministery of Health, Coordenadoria Nacional - DST/Aids, PNUD 038/94. This protocol was approved by the Ethics and Research Committee HC-FMUSP no 289/93.
NUNES DF e col. - Atividade lítica de células natural "killer" durante a infecção pelo HIV-1 em indivíduos brasileiros. Rev. Hosp. Clín. Fac. Med. S. Paulo 56(3):75-78, 2001.

As células "natural killer" são consideradas importante componente da resistência inata às viroses, mas seu papel na infecção pelo HIV é controverso. Alguns investigadores verificaram que as células "natural killer" não possuíam qualquer efeito protetor durante a progressão para doença, enquanto outros têm mostrado que as mesmas podem ser protetoras e retar- dar a progressão para doença, tanto devido à sua ação lítica como pela supressão por quimocinas. Em nosso estudo, analisamos as alterações funcionais na atividade durante infecção pelo HIV-1 usando ensaio com células K562 como alvo. Os resultados mostraram que a atividade "natural killer" está diminuída somente nas fases mais avançadas da doença e somente quando foi utilizar um número elevado de (40:1) células efetoras-alvos. A diminuição da atividade neste estágio da doença pode estar relacionada com a imunossupressão grave; a presença de alguns fatores virais, como a gp120 e gag, que interferem como a capacidade de ligação das células "natural killer"; ou a redução da produção de citocinas que estimulam a atividade "natural killer", como IFN-a e IL-12, por monócitos, uma subpopulação de células que são afetadas somente nos estágios mais avançados da infecção HIV. Assim, fica sugerido que a diminuição da atividade "natural killer" pode contribuir para alterações no sistema imune de pacientes nas fases avançadas da infecção HIV.

\section{DESCRITORES: Infecção pelo HIV. Células "natural killer".}




\section{REFERENCES}

1. TRINCHIERI G - Biology of natural killer cells. Adv Immunol 1989;47: 187-376.

2. LOPEZ C, FITZGERALD PA, SIEGAL FP et al. - Deficiency of interferon-alpha generating capacity is associated with susceptibility to opportunistic infections in patients with AIDS. Ann New York Acad Sci 1984;437: 39-48.

3. HOWELL DM, FELDMAN M, SIEGAL FP et al. - Peripheral blood of AIDS patients contains cells capable of providing accessory function for the natural killer cell-mediated lysis of herpes simplex virus-infected targets despite low interferon-alpha production. JAIDS 1993;6: 15-23.

4. ULLUM H, GOTZSCHEP PC, VICTOR J et al. - Defective natural immunity: an early manifestation of human immunodeficiency virus infection. J Exp Med 1995;182: 789-799.

5. CAI Q, HUANG XL, RAPPOCCIOLO G et al. - Natural killer cell responses in homosexual men with early HIV infection. JAIDS 1990;3: 669-676.

6. BRASIL - Ministério da Saúde. AIDS: Boletim Epidemiológico. Brasília, Programa Nacional de DST/AIDS, 1999. Ano 11, n. 3.

7. CASSEB JS, BENARD G, SAITO R et al. - Value of PHA lymphocyte proliferation test in the immune evaluation of HIV-infected patients in Brazil. J Invest Allerg Clin Immunol 1995;5: 347-349.

8. CDC - 1993 revised classification system for HIV infection and expanded surveillance case definition for AIDS among adolescents and adults. MMWR 1992;41: 1-19.
9. AHMAD A \& MENEZES J - Defective killing activity against gp120/ 41-expressing human erythroleukaemic K562 cell line by monocytes and natural killer cells from HIV-infected individuals. AIDS 1996;10: 143-149.

10. LIN SJ, ROBERTS RL, ANK BJ et al. - Human immunodeficiency virus (HIV) type-1 GP120-specific cell-mediated cytotoxicity (CMC) and natural killer (NK) activity in HIV-infected (HIV+) subjects. Clin Immunol Immunopathol 1997;82: 163- 173.

11. LOUBEAU M, AHMAD A, TOMA E \& MENEZES J - Enhancement of natural killer and antibody-dependent cytolytic activities of the peripheral blood mononuclear cells of HIV-infected by recombinant IL-15. J Aids Human Retrovirology 1997;16: 137-145.

12. GOICOA MA, IANNITELLI PS, DIEZ RA et al. - Natural killer suppressor factors in sera from HIV-infected subjects. Scand J Immunol 1995; 41:L 523-528.

13. OLIVA A, KINTER AL, VACCAREZZA M et al. - Natural killer cells from human immunodeficiency virus (HIV)-infected individuals are an important source of CC-chemokines and suppress HIV-1 entry and replication in vitro. J Clin Invest 1998; 102: 223231.

14. NAIR MP \& SCHWARTZ AS - Inhibition of natural killer cell activities from normal donors and AIDS patients by envelope peptides from human immunodeficiency virus type I. Cell Mol Biol 1997;43: 969-979.

Received for publication on March 20, 2001 